\title{
Correction to: The Future of International Solidarity in Global Refugee Protection
}

\section{Obiora Chinedu Okafor ${ }^{1}$}

Published online: 7 December 2021

(c) Springer Nature B.V. 2021

\section{Correction to: Human Rights Review (2021) 22(1):1-22 https://doi.org/10.1007/s12142-020-00587-w}

This article was intended for inclusion in the Special Section on The Spirit of International Solidarity, the Right to Asylum, and the Response to Displacement. It was, however, published in a separate issue, Volume 22, Issue 1, 2021 and is available at https://doi-org.ez.library.latrobe.edu.au/10.1007/s12142-020-00587-w.

Also, the author is now at the School of Advanced International Studies, Johns Hopkins University and his new email is: ookafor6@jhu.edu.

Publisher's Note Springer Nature remains neutral with regard to jurisdictional claims in published maps and institutional affiliations.

The original article can be found online at https://doi.org/10.1007/s12142-020-00587-w.

Obiora Chinedu Okafor ookafor6@jhu.edu

1 School of Advanced International Studies, Johns Hopkins University, Washington, DC 20036, USA 